\title{
Can Executive Academic Experience Help Companies Improve Their Innovation? Empirical Study of Chinese Listed It Companies
}

\author{
Hongjun Zeng \\ Business School \\ Guangxi University \\ Nanning, China \\ E-mail:hongjunzeng@protonmail.com
}

\begin{abstract}
In recent years, as the largest emerging market, China's economic development has gradually shifted from the high growth stage to the high-quality development stage. Company is an essential micro-subject of macroeconomic activities, and an entrepreneur's academic background is a critical factor in achieving high-quality corporate development. This study takes the data of IT listed companies in China from 2012 to 2017 as the sample, Screening research samples based on academic experience requirements based on requirements for current or former teaching and research positions in universities, then makes an empirical analysis on the connection between academic executives and companies innovation ability. The results indicate that there is a significant positive correlation between executive academic experience and company's innovation ability, i.e., academics-type. There is also a significant positive correlation between the average tenure of executives and innovation ability, which still holds after robustness test. Researching the relationship between the academic experience of the executives of listed companies and their innovation ability can not only enrich the research on the characteristics of senior management team, but also provide theoretical guidance for the construction of senior management team, and provide a few suggestions for the improvement of innovation ability and the formulation of government-related policies.
\end{abstract}

\section{Keywords: Executive Team, Academic Experience, Corporate Innovation, Chinese Listed It Companies.}

\section{Introduction \\ I.I Research Background}

At present, the trans-nationalization of business activities accelerates the development of companies, companies face complex and ever-changing environment, and the importance of the distinctive and scarce human capital with the high added value of knowledge and skills of senior managers is increasingly highlighted (Buckley et al., 2010). After the upper echelons theory was put forward (Hambrick \& Manson, 1984), more and more researches began to pay attention to the relationship between executive team characteristics and companies development. The excellent senior management team has become an essential part of the core competitiveness of companies, which can help companies improve their internal management and further improve their business performance (Kaplan et al., I99I). It is also a key factor for some companies to continuously promote innovation.

There has been much analysis on innovation factors in the current academic researches, including financial supervision based on macroeconomics, etc.; legal policy based on the perspective of regional economy; social capital, corporate competitiveness, and industry competition on the companies external environment; and corporate incentive mechanism, financial performance and corporate governance structure on the internal environment that will also affect the investment and put the resource into innovation (Wright et al., 2008). Executives play an essential role in internal decision-making and corporate governance. As the formulation and executor of corporate strategic decision-making, it plays an irreplaceable role in the development of corporate innovation ability (Tan, 200I).

China attaches great importance to promoting the development of market economy and innovation mechanisms. The market economy mechanism is increasingly consummate, and the economy develops rapidly, attracting the talents with academic experience from universities and scientific research institutes to enter the companies and become the emerging backbone of company's development. Many talents have entered the senior management circle of the companies. Academic-type executives are knowledgeable and skilled (Liu et al., 20I I).

With the issuance of the notice on several policies and measures for promoting collaborative innovation in the issuance, Several opinions on implementing the policy of orienting Increasing the Value of Knowledge as the Orientation which by the Central General Office of the CCP (Chinese Communist Party) and the General Office of the National Council on November 7, 2016, the number of senior executives with academic experience has grown increasingly, accordingly, academictype executives account for $38 \%$ of the total samples of company executives. 
The rapid economic development brought about by the explosion of Internet technology in the new era has enabled global companies to perceive the significant role of scientific and technological innovation fully. The innovation ability of companies is an essential source for companies to maintain the competitiveness of the whole industry. China still has shortcomings in innovation now. Improving companies innovation will help promote the development of China's overall economy and enhance the construction of innovative countries (Teece, 2010).

In contemporary, scholars have studied the influence of academic-type executives and corporate debt financing costs, corporate performance, social capital, and corporate innovation. Academic-type executives can play a better management communication function, and ultimately improve corporate debt costs and corporate financial performance by improving corporate innovation performance and thus promoting business performance at all (Kaplan \& Norton, 200I).

The senior management is an essential part of the human resources of the companies. How to better play the role of this extraordinary resource and enhance company's overall management ability and is a crucial issue bound by the survival and development of the companies in the new era (Peterson, 2004). This study analyzes the effect of the senior management team with academic experience on the innovation of information technology companies by taking the information technology industry as the research object. On the one hand, it expects to provide some suggestions for the innovation policy and talent introduction plan of China; on the other hand, it also expects to improve the theoretical basis and suggestions on whether companies should introduce academic-type executives and strengthen the innovation ability of companies.

\section{I.2 Contents and Methods of Research}

This study focuses on the impact of senior executives' academic experience on the innovation ability of listed IT companies in China. The purpose of research and innovation ability lies in the short-board of innovation in China. The rise of innovation capacity is an essential factor to improve the competitive ability of companies (Li et al., 2006; Chen et al., 2004). Besides, previous studies have confirmed the decisive role of the academic experiences of executive teams on corporate innovation performance. However, there are also studies showing that academic-type executives face many challenges when operating companies in China. From the perspective of asset complementary, it is found that longer tenure can help academic-type executives better integrate into the company environment and complement their advanced expertise and management skills, thereby improving corporate innovation performance (e.g. Damanpour \& Marguerite, 2006; Mom et al., 2015).

The academic experience of executives will make companies more cautious when making risky decisions, to reduce corporate risk and improve their risk-averse ability (Opper et al., 2017); meanwhile, the academic experience of executives can strengthen the self-supervision and restraint of senior executives and reduce the risk of unreasonable innovation input (Chon, 20I7). Thus, this study expects a positive relationship between the academic experience of executives and companies innovation ability. Based on the theory of asset complementary, this study argues that with the increase of tenure, the academic-type executives can gradually accumulate the knowledge of the companies environment and management experience, to better play the role of senior management team academic experience to promote innovation performance.

The academic experience of executives means that executives have gone through more rigorous skills-only training and will rely more heavily on expertise in their analysis and decision-making (Hinterhuber, 2004; Lämsä \& Takala, 2000). The academic experience can make executives more innovation-conscious and value innovation simultaneously, thereby increasing the overall investment awareness and development awareness of the executive team toward innovation (Matthyssens et al., 2006; Zahra, 1995). According to this, the academic experience of executives will make the company more investment in innovation, to be more sensitive to the perception of market-oriented innovation and better guide the direction of company innovation development (Lee \& Tsai., 2005; Menguc \& Auh., 2006). Therefore, it is reasonable to believe that the academic experience background of the senior management team can effectively improve the decision-making efficiency, work efficiency and company profit rate of the senior management team in the treatment of innovation investment, thus improving the innovation ability level of the whole company and promoting the rapid development of the company (Forbes, 2005; Cui et al., 2019).

\section{I.3 Framework of the Study}

Based on the existing research, this study firstly judges whether the academic experience has a positive effect or direct effect on the companies through theoretical knowledge. Next based on the framework of theoretical analysis, a measurement model of the relationship between executive academic experience and company's innovation ability is established, and the data of listed companies in China IT industry from 2012 to 2017 is selected as the research sample for empirical testing. Then the parameter estimation and hypothesis testing of the model are carried out by using the measurement method, and the influence of the executive academic experience on the patent application of innovation ability index of the explained variable enterprise is obtained, and the robustness is tested. 


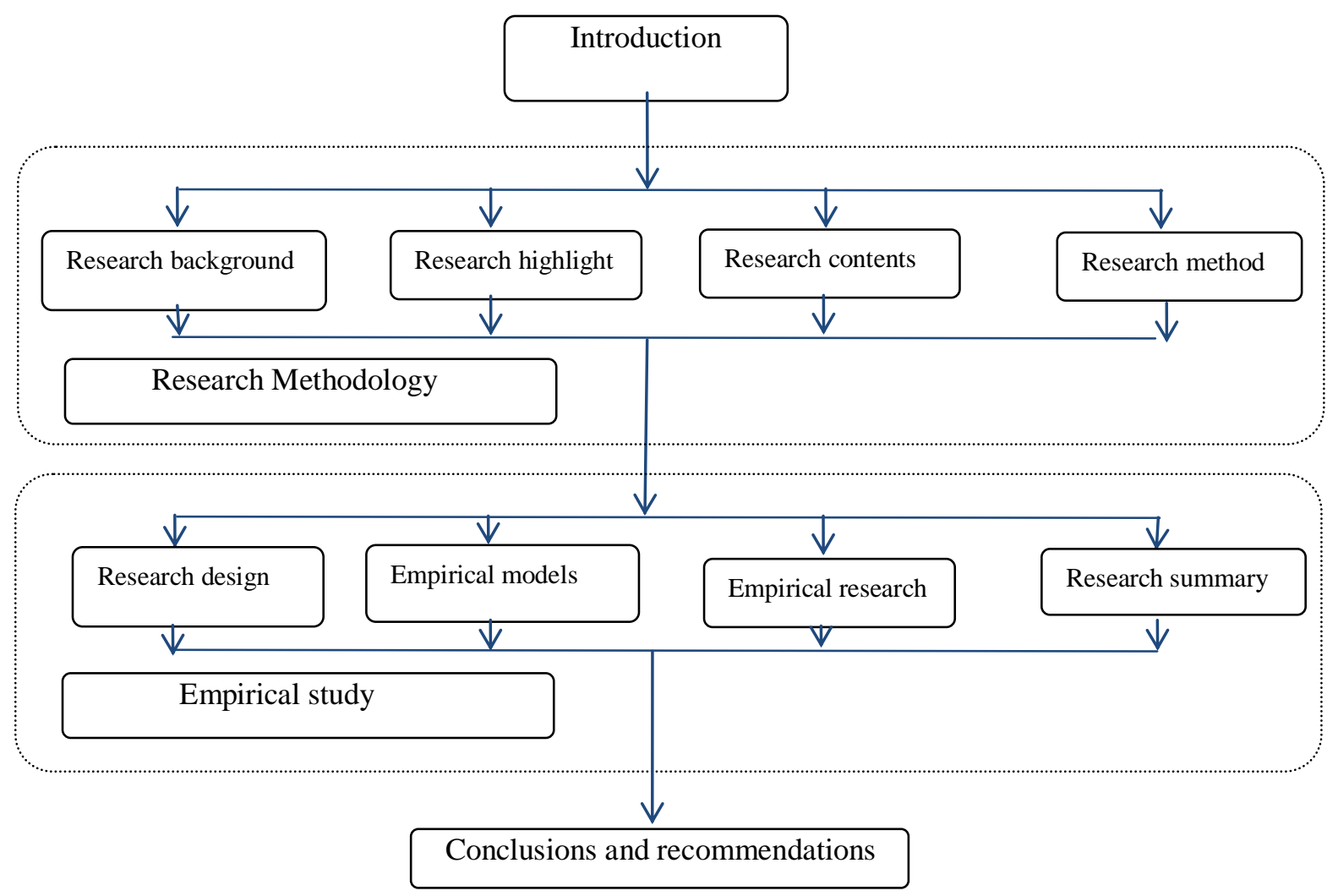

Figure I. Study Framework

\section{I.4 Feasibility and Highlight of Research}

The research plan for this project is feasible, and the main manifestations are as follows:

- This research topic has sound inherent logic, and the research content is also more specific, the establishment of the model is operable. First of all, the academic experience of executives and innovation ability of the theoretical logic analysis, and then establish a model of the relationship between the promotion of quantitative analysis of the model and test analysis of the model for the development of companies.

- The data source of this study topic is relatively reliable. Through the quantification and test established by the econometric model, the obtained results have outstanding reference value for the companies to hire an executive team, improve the enterprise innovation ability and profitability.

At present, the world economy faces transformation and development, and the major companies are actively introducing senior academic talents to improve their innovation ability. Thus, this study focuses on the theme of "the influence of executive academic experience on company innovation ability."

First, this study takes the academic-type executives of listed companies in IT industry of China as the object of discussion. It makes a comprehensive analysis of its role in companies innovation ability, which makes the research on the relationship between executive team characteristics and companies development deep into the personal characteristics of executives, and the research object is the whole executive team, and the research contents are company-scale, executive team size, the number of academic-type executives and company innovation ability.

Furthermore, this study takes the academic-type executives as the centre, tests the correlation between the companies innovation ability and the academic-type executives, also adds the relevant control variables, from the traditional research characteristics into a new track of background research, provides a new research perspective for the "upper echelon theory."

On top of this, this study enriches the research on the effect of executive academic experience on company's innovation ability. Previous studies have found that the academic background of executives is positive correlated to the development of companies, such as improving corporate governance, increasing debt financing ratio, exerting information consulting function. Nevertheless, a few kinds of literature comprehensively consider the impact of the academic experience of executives on corporate innovation ability. 


\section{Literature Review}

With the development of the world economy, the internal and external environment of the company has become more sophisticated, individual decision-making has been challenging to adapt to the status quo, and team decision-making has begun to become mainstream. Hambrick \& Mason (1984) proposed the "upper echelons theory," which states that the decisionmakers should be teams rather than individuals; the senior management team can better manage the company's decisions. The psychological structure of the senior management team, such as cognitive, perceptual characteristics, and values cannot be quantified but should focus on other characteristics of the executive team, such as the average age, tenure, executive professional and educational background. Many new elements have been added and revised to the models of the upper echelon theory in the following studies. The interaction between the elements has also been considered. Since then, the basic framework of "upper echelon theory" has been established.

Based on demographics, (Wang, 2014) explores the correlation between the demographic characteristics of executive teams and corporate innovation capacity. His paper studies the influence of the demographic characteristics and social capital of the executive team on the innovation ability of the company. The study found that the social capital of executives was significantly positively correlated with the innovation ability of companies, but had no significant effect in the short term.

Based on the characteristics of the executives studying abroad, (Mo, 2016) analyzes the influence of the overseas background of the executive team of listed companies in China's electronic equipment manufacturing industry on their innovation performance under the comprehensive perspective of internal governance and external governance, and concludes that the political and commercial ties of the executives with overseas background have an inverted U-shaped regulation on the relationship between the characteristics of the overseas background of the executive team and the return on net assets; The results indicated that the (Huang \& Ge, 2018) believes that China's huge market potential and employment opportunities continue to attract overseas immigrants and overseas students. In the period of transition from high economic growth to high quality in China, overseas returned executives play a crucial role in promoting company innovation; (Zhou, 2018) divides the executive team into $\mathrm{CEO}$ and non-CEO according to their overseas experience, and divides them into overseas work background and overseas study background according to their overseas background, and uses empirical analysis to investigate the relationship between the human capital characteristics and innovation performance.

Based on social capital and company performance aspects, (Jinhua, 2010) argues that for executive teams, social capital is difficult to measure practically, researching this area still at the level of theoretical analysis. He mainly studies the social characteristics of the executive team, makes an empirical analysis of the relevant social capital to the company development, and provides some enlightenment for the company how to use this social capital. It is of considerable significance to know-how companies operate to social capital.

Besides, (Lopez-de-Silanes, 2017) believes that in recent years, more and more highly educated talents have entered the company and emerged in the enterprise as a new force. Scholars and governments pay more and more attention to their role in the domestic economy. (Hollenbeck \& Jamieson, 2015) analyzed the "senior management team," "corporate performance evaluation," senior management team characteristics, and corporate performance. " The research result in the average level of education of senior management team has no noticeable effect on the short-term performance of the company, but has a significant positive correlation with the long-term performance of the company. (Kenney et al., 2013) mainly considers the relationship between the background characteristics of senior management and the business performance of the company. She takes the small and medium-sized high-tech listed companies as the research object and uses the panel model and the fixed effect model to carry on the empirical analysis. The research shows that the educational background of the executives has a significant positive correlation with business performance. The higher the education levels of the executives, the better the business performance. Innovation is a crucial indicator in high-tech listed companies, and the higher the education level of executives can effectively improve the innovation ability of companies.

Consequently, this study selects the executives with academic experience as the research object, and the research direction is to focus on the analysis of the impact of this human capital factor on enterprise innovation ability, research into the role of executive age, gender, companies size, tenure on enterprise innovation ability, enriched the research on the characteristics of the senior management team for companies innovation development.

\section{Theoretical Analysis and Hypothesis Proposal}

\section{I Academic Executives and Enterprise Innovation Ability}

As a group different from ordinary executives, academic-type executives have a lot of unique knowledge, psychology, community resource, and other capital. Will these characteristics have a positive effect on innovation ability? Are academic-type executives separated from all sample executive teams based on academic experience? However, there are still characteristic differences among academic-type executives themselves, and will these differences affect corporate innovation capacity? For addressing above problems, this chapter attempts to analyze the effect of academic-type executives and their characteristics on company's innovation ability from the theoretical level according to the theory of upper echelon and puts forward the corresponding research hypothesis. 
The academic experience background of an executive implies a quality education. Academic-type executives generally have advanced knowledge and skills, have received rigorous academic training, and have a deeper understanding of the development requirements of advanced technology. Academic-type executives generally have a keen sense of innovation in the professional field, have an advantage in technical level innovation breakthroughs, and can use their excellent professional knowledge to judge the situation. Thus, academic-type executives are essential human resources of companies, which can effectively help companies form core competitiveness, discover the gap between the company and competitors in the same industry, and quickly discover and seize innovation opportunities, thus enhancing the overall innovation level of companies (Porter \& Kramer, 2019).

Academic-type executives have advantages not only in knowledge but also in psychology. In companies, academic-type executives tend to be more confident in their decision-making, preferring risk, and innovation. In recent years, some researchers have found that the psychological capital of academic-type executives can effectively promote the development of companies. That is because the psychological capital of academic-type executives allows them to view risky corporate decisions optimistically and judgmentally on delicate items, preferring risks and challenges, and even more so on innovation investments (E.g. Amunkete \& Rothmann, 2015).

Besides, academic experience enables executives to accumulate a certain amount of social capital when they upgrade their abilities, and they can use academic experience and background to form a unique network of contacts to bring social capital advantages to companies (Erickson, 2017). It will be an essential advantage for companies to capture new technology and experience that academic-type executive can capture the latest innovation and scientific and technological achievements through similar social networks.

The following research hypothesis $\mathrm{H}_{\mathrm{I}}$ is proposed:

\section{$\mathrm{H}_{\mathrm{I}}$ : Academic-type executives have a positive correlation with companies' innovation ability.}

The correlation between the tenure of Office of academic-type executive and the creative ability of companies . Studies have shown that academic executives face many challenges when they start to rule companies. The academic experience of the executive team has relatively reduced its management experience and work experience in the companies. Academic-type executives may lack a comprehensive and profound understanding of the internal and external environment of the companies in a complicated situation, and it is challenging to respond in a timely and effective manner. These issues have limited the academic experience of the executive team to a certain extent to play further to improve the management capacity of the companies (Simsek, 2009; Hollenbeck \& Jamieson , 2015). The road to innovation is full of uncertainty, often requiring a large number of tests to complete the perfection of an innovative technology or experience, which makes a successful innovation requires a more extended period of advanced and effective top-level design. Thus, after entering the companies, academic-type executives need time to gradually improve the innovation environment to improve the innovation ability and efficiency of the companies. The longer the tenure of Academic-type executives, the more significant impact on the innovation ability of companies.

The following research hypothesis $\mathrm{H}_{2}$ is proposed:

$\mathrm{H}_{2}$ : Term of the office plays a decisive regulatory role in the correlation between academic-type executives and companies innovation ability.

\section{Research Preparation}

\section{I Sampling Procedures and Data Sources}

Based on the analysis of the above sections, to test the above hypotheses $\mathrm{HI}$ and $\mathrm{H} 2$, this chapter mainly discusses the sample selection, data collection, setting variables, and so forth. To prepare for the establishment of the model from the empirical point of view. First, select the I65 classification items under the China Securities Regulatory Commission (CSRC) 2012 classification: the IT industry is the research sample; subsequently, the corresponding variables are proposed based on the above research assumptions and analysis; ultimately, an econometric model is established and tested and analyzed.

Considering that China is currently in the stage of strategic transformation, and in the plan of the I3th five-year plan, the information technology industry has become the main driving force for China's economic development. The development of the information technology industry in China mainly depends on the input and innovation of talents with outstanding academic backgrounds, which has played an enormous role in promoting the revolution of the information industry. Consequently, according to the latest 2012 CSRC industry classification standard, this paper selects the I65 Industry: Information Technology Industry listed companies as the initial sample, from 2012 to 2017.

The screening of initial samples is based on the following rules: select non-ST samples; select samples that can obtain accurate background information of executives; and select samples with the more comprehensive necessary information and innovation ability of companies. Considering that the influence of executive characteristics on the development of the company has a lag, accordingly, the sample data is explained by the variables of the delay period. Lastly, a sum of 25,97 I sample data of 
2,I05 listed companies in Shanghai and Shenzhen A-share information technology industry listed companies were obtained from 2012 to 20I7, of which I,755 were sample companies with academic experience.

The number of patent applications used in the innovation index of this paper comes from the innovation database of listed companies in China's "Guotai An", and the background information of executives comes from the governance structure database of "Guotai An" and "Ruisi" database. Severally of the missing necessary company information or executive background information will be completed by consulting the company's annual report and financial website news and statistical annual report. The software used in the data processing and empirical analysis of the model was Excel and STATA, respectively.

\subsection{Statistical Approach}

- Executive Academic Experience: This study defines the executive academic experience as the experience that the executive is or has been teaching in universities and scientific research institutes. To ensure that the academic experience of the executive team is accurate and valid, the actual number of academic executives in the executive team is used as the explanatory variable.

- Mean Tenure of Academic-Type Executives: Considering that the academic-type executives have a certain adaptive period after entering the company to fit the work and decision-making environment better, the average tenure of executives in the companies as an explanatory variable was added to the model.

- Company Innovation Ability: For innovation ability, patent application means independent intellectual property rights and innovation technology. Many scholars use the number of patent applications as a measure of innovation ability. For this reason, this study uses the number of patent applications to represent the innovation ability of companies. To avoid the issue of endogeneity, the logarithm of the number of patent applications is taken as the explained variable.

- Control Variables: Based on the previous scholars' research on "upper echelon theory," this paper selects the company size, the companies operating years, and executive team size, the executive average age, the proportion of female executives as the control variables, besides, for each year of data in the empirical analysis of the annual control dumb variable processing.

\subsection{Experimental Manipulations}

Two multiple linear regression models were established to test the above study hypotheses. Model I is used to examine the effect of executive academic experience on innovation performance, and Model II is used to examine the moderating effect of tenure on the correlation between executive academic experience and innovation performance. In order to have a proper analysis of the data sourced, the STATA I5.0 was used.

Model I:

$$
\begin{aligned}
& \text { Innovation }_{i, t+1}=\alpha+\beta_{1} \text { Acedemic }_{i, t}+\beta_{2} \text { Size }_{i, t}+\beta_{3} \text { Age }+ \\
& \beta_{4} \text { ETsize }_{i, t}+\beta_{5} \text { ETage }_{i, t}+\beta_{6} \text { female }_{i, t}+\text { Year }+\varepsilon
\end{aligned}
$$

Model II:

$$
\begin{aligned}
& \text { Innovation }_{i, t+1}=\alpha+\beta_{1} \text { Acedemic }_{i, t}+\beta_{2} \text { Tenure }_{i, t}+\beta_{3} \text { Acedemic }_{i, t} \\
& \times \text { Tenure }_{i, t}+\beta_{4} \text { Size }_{i, t}+\beta_{5} \text { Age } \beta_{6} \text { ETsize }_{i, t}+\beta_{7} \text { ETage }_{i, t} \\
& +\beta_{8} \text { female }_{i, t}+\text { Year }+\varepsilon
\end{aligned}
$$

Among them: $i, t$ represent the sample company and the year of observation; $\alpha$ is the model intercept; $\beta$ to $\beta 8$ are regression coefficients of the model; $\varepsilon$ is possible interference items of the model. In order to eliminate the influence of the extreme values on the regression model, $1 \%$ and $99 \%$ shrinkage treatment is performed on all variables. Auto-correlation test is performed first, then statistical analysis is performed, then a regression model is constructed, and finally the model is tested for robustness.

\section{Analysis and Finding}

Based on the theoretical analysis and research design above, this chapter begins to test the impact of academic-type executives on company's innovation empirically. Firstly, this chapter makes a preliminary analysis of academic-type executives and innovation ability through descriptive statistics and correlation analysis; moreover, empirically tests the impact of academic-type executives on company innovation, and discusses the subsequent impact of academic-type executives' tenure on company innovation based on the test results. After that, this chapter discusses the effect of academic-type executives' innovation behavior on company's 
value based on the consideration that company innovation consequence benefit maximization. Eventually, to enhance the reliability of the results, this chapter also conducts a series of robustness tests of model.

\section{I Descriptive Statistics and Correlation Analysis}

About distribution of the number of executives in the sample between 2012 and 2016, China's IT industry grew from 345 to 489 listed companies, while the total number of academic-type executives rose from 284 to 425 , and the number of executive teams increased from 4359 to 6I24. Generally, as the number of listed companies increased, the total number of executives increased, while the proportion of academic executives increased from $6.52 \%$ in 2012 to $6.74 \%$ in 2016 , during which time it had reached the peak of $6.94 \%$, see table I.

Table I. Frequency distribution of executives with academic experience

\begin{tabular}{lllll}
\hline Year & Number of companies & $\begin{array}{l}\text { Number of academic } \\
\text { executives }\end{array}$ & $\begin{array}{l}\text { Executive } \\
\text { team size }\end{array}$ & $\begin{array}{l}\text { Proportion of academic } \\
\text { executives } / \%\end{array}$ \\
\hline 2012 & 345 & 284 & 4359 & $6.52 \%$ \\
\hline 2013 & 394 & $3 \mathrm{II}$ & 4686 & $6.64 \%$ \\
\hline 2014 & $42 \mathrm{I}$ & 345 & $5 \mathrm{I} 29$ & $6.73 \%$ \\
\hline 2015 & 456 & 390 & 5673 & $6.87 \%$ \\
\hline 2016 & 489 & 425 & 6124 & $6.94 \%$ \\
\hline Total & $2 \mathrm{I} 05$ & 1755 & 25971 & $6.74 \%$ \\
\hline
\end{tabular}

Results of variable descriptive statistics for the full sample and the sub-sample of academic-type executive companies. In the full sample, the mean value of corporate innovation capacity was 3.I8I, and the average number of academic-type executives was 0.175, while the mean value of corporate innovation capacity in the sub-sample was 3.298. The average number of academic-type executives was 1.644. This indicates that the average number of corporate innovation and academic-type executives in the sub-sample is higher than the corresponding variables in the full sample, and the specific reasons also need further empirical analysis and identification of the correlation between the variables, see table 2 .

Table 2. Descriptive statistics of the main variables

\begin{tabular}{|c|c|c|c|c|}
\hline \multirow[t]{2}{*}{ Variable } & \multicolumn{2}{|c|}{ Full sample $(\mathrm{n}=2 \mathrm{I05})$} & \multicolumn{2}{|c|}{$\begin{array}{l}\text { Academic executive team sub-sample } \\
(\mathrm{n}=\mathrm{I055})\end{array}$} \\
\hline & Mean & Standard deviation & Mean & Standard deviation \\
\hline Innovation & $3.18 I$ & I.22I & 3.298 & 1.399 \\
\hline Academic & 0.175 & 0.086 & 1.644 & 0.787 \\
\hline Tenure & $4.2 \mathrm{II}$ & 2.495 & $4.17 \mathrm{I}$ & 2.427 \\
\hline Size & 7.261 & 1.097 & 7.381 & 1.025 \\
\hline Age & $\mathrm{I} 4.848$ & 5.279 & $\mathrm{I} 4.2 \mathrm{I} 8$ & 5.519 \\
\hline ETsize & I8.679 & 5.124 & 6.447 & 2.185 \\
\hline ETage & 43.239 & 2.125 & 42.093 & 2.925 \\
\hline ETFemale & 0.321 & 0.120 & $0.42 \mathrm{I}$ & 0.102 \\
\hline
\end{tabular}

Note: All variables have been processed with $1 \%$ and $99 \%$ shrinkage.

After descriptive statistics, the main variables in the model were tested for auto-correlation and multi-collinearity. The results noticed that the maximum VIF (variance inflammation factor) was 2.34, and the average VIF was I.49, which were all less than 5, representing that there was no multi-collinearity among the main variables. Pearson correlation analysis of the variables, in which the correlation coefficient between innovation performance and academic-type executives is 0.075 , and the correlation between average tenure of academic-type executives is 0.062 , and all of them are significant at the level of $1 \%$, see table 3 . 
Table 3. Pearson correlation analysis of the main variables

\begin{tabular}{|c|c|c|c|c|c|c|c|c|}
\hline Variable & Innovation & Academic & Tenure & Size & Age & ETsize & ETage & ETfeamle \\
\hline Innovation & 1.000 & & & & & & & \\
\hline Academic & $0.075^{x}$ & 1.000 & & & & & & \\
\hline Tenure & $0.062^{x}$ & 0.463 & 1.000 & & & & & \\
\hline Size & $0.469^{\text {*x }}$ & $0.053^{\text {米 }}$ & $0.092^{x}$ & 1.000 & & & & \\
\hline Age & 0.I I0 & -0.050 & 0.036 & 0.109 & 1.000 & & & \\
\hline ET size & $0.190^{x}$ & $0.408^{x}$ & $\begin{array}{l}- \\
0.026^{2}\end{array}$ & 0.239 & $0.203^{x}$ & 1.000 & & \\
\hline ET age & 0.032 & $0.32 \mathrm{I}$ & 0.344 & $0.2 \mathrm{I} 2$ & $0.338^{2}$ & $0.329^{x}$ & 1.000 & \\
\hline ET Female & $-0.100^{2}$ & 0.099 & $\begin{array}{l}- \\
0.097\end{array}$ & $\begin{array}{l}- \\
0.159 \\
\end{array}$ & $0.06 I^{1}$ & $\begin{array}{l}- \\
0.205\end{array}$ & $\begin{array}{l}- \\
0.128\end{array}$ & 1.000 \\
\hline
\end{tabular}

Note: means $\mathrm{p}<0 . \mathrm{I0}$; means $\mathrm{p}<0.05 ;$

\subsection{Regression Results and Analysis of Models}

A regression analysis was performed on the model. Model examines the impact of academic-type executives as well as control variables on company innovation ability, and Model examines the impact of academic-type executives' average tenure as well as control variables on company innovation ability. The multiple linear regression results of Model indicated that the academic experience of senior executives could significantly increase the innovation ability of companies, and the regression coefficient of the variable of senior academic-type executives in the model was 0.634 , which was significant at $5 \%$ level. It can be proving that the larger the number of academic-type executives in the executive team, the higher the number of patents of the companies and the stronger the innovation ability of the companies. Hence $H_{I}$ is supported. The multiple linear regression results of model indicate that the average tenure of academic-type executives will also significantly increase the innovation ability of companies. The regression coefficient of the variable of average tenure of academic-type executives in model is 0.665 , which is significant at the level of 5\%. It can be prove that the longer the average tenure of academic-type executives is, the more the number of corporate patent applications will be, thus improving the innovation ability of companies. $\mathrm{H}_{2}$ is supported later.

The regression coefficients of the control variables from the regression results of the two models, in which the regression coefficients of companies size "Size", companies operating years "Age", executive team size "ET size" and executive average age "ET age" account for a small proportion, and the difference between the two models is not significant, indicating that there is no significant correlation between these control variables and the explained variables. Besides, the regression coefficients of female executives in both models were negative and significant at the level of $10 \%$, indicating that the participation of female executives in enterprises is not conducive to improving corporate innovation, see table 4 .

Table 4. Multiple Linear Regression Models

\begin{tabular}{|c|c|c|}
\hline \multirow{2}{*}{ Variable } & \multicolumn{2}{|c|}{ Innovation } \\
\hline & Model I & Model II \\
\hline Aademic & $0.634^{x-x}$ & \\
\hline Tenure & & $0.665^{\text {xhy }}$ \\
\hline Size & $0.307^{\text {tax }}$ & $0.208^{* x}$ \\
\hline Age & 0.093 & 0.104 \\
\hline ETsize & 0.195 & 0.156 \\
\hline ETage & 0.008 & 0.031 \\
\hline ETFemale & 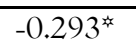 & $-0.164^{*}$ \\
\hline Year & control & control \\
\hline Intercept term & -1.656 & -1.47 \\
\hline Observations & 2105 & 2105 \\
\hline Adejusted R2 & $0.18 \mathrm{I}$ & 0.176 \\
\hline
\end{tabular}




\subsection{Robustness Analysis}

For improving the reliability of the model conclusion, the robustness test is adopted to test the above model results. In this study, the alternative index method is used to replace the number of academic-type executives of the explanatory variable $\mathrm{I}$ in the model with the academic-type executives dummy variable Academic dummy, if the company has academic-type senior management I, no academic-type senior management 0 ; the explanatory variable company innovation ability (company patent application number is treated as the natural logarithm) in the model is replaced by the ratio R/I of company $R \& D$ investment to company operating income, to examine whether companies increase innovation investment. Regression analysis was performed on the model after replacing the indicators. In models I and II, the regression coefficients of dummy variable of replaced academic-type executives are 0.I62 and 0.I48, respectively, and both of them are significant at the level of 5\%, indicating that academic-type executives are still positively correlated with companies innovation ability, hence the above model results are robust, see table 5 .

Table 5. Robustness test

\begin{tabular}{|c|c|c|c|c|}
\hline \multirow[t]{2}{*}{ Variable } & \multicolumn{2}{|c|}{ Innovation } & \multicolumn{2}{|l|}{$\mathrm{R} / \mathrm{I}$} \\
\hline & Model I & Model II & Model I & Model II \\
\hline Academic dummy & $0.162^{x}$ & $0.148^{x}$ & & \\
\hline Academic & & & $0.12 I^{x}$ & 0.109 \\
\hline Tenure & & $0.109^{x}$ & & $0.108^{x}$ \\
\hline Size & $0.656^{\text {th }}$ & $0.647^{\text {* }}$ & $0.412^{\text {tx }}$ & $0.43 I^{\text {* }}$ \\
\hline Age & 0.153 & 0.099 & 0.009 & 0.024 \\
\hline ETsize & 0.201 & 0.242 & 0.042 & 0.122 \\
\hline ETage & 0.042 & 0.098 & $0.09 \mathrm{I}$ & 0.118 \\
\hline ETFemale & $-0.052^{\text {市 }}$ & $-0.086^{\text {栍 }}$ & $0.325^{\text {方 }}$ & $0.297^{\text {柿 }}$ \\
\hline Year & control & control & control & control \\
\hline Intercept term & -3.322 & -4.313 & -4.532 & $-8.32 \mathrm{I}$ \\
\hline Observations & 2105 & 2105 & 2105 & 2105 \\
\hline Adejusted R2 & 0.212 & 0.201 & 0.125 & 0.164 \\
\hline
\end{tabular}

\section{Conclusion and Recommendation}

\section{I Conclusion}

According to the research in this article, using the data of listed companies in China's Shanghai and Shenzhen A-share IT industry from 2012 to 2017 as the research sample, then using STATA to conduct an empirical analysis and robustness test on the relationship between executive academic experience and company debt financing costs. The conclusions as follow:

First, Academic-type executives have a significant role in promoting the innovation of companies, which is manifested as academic knowledge, psychological capital, and community resource of academic-type executives, which helps to enhance the decision-making capacity of companies, thus promoting the innovation of companies. This conclusion was made after a series of robustness tests.

Furthermore, the tenure of academic-type executives plays a decisive regulatory role in the relationship between the academic experience of executives and corporate innovation ability. The return of the average tenure of the academic-type executives and the corporate innovation ability is significant, which achieves that the extension of the academic-type executives' tenure in the company can make up for their disadvantages in the company's resources, internal and external environment, and community resource, to gradually strengthen management ability, which is conducive to the improvement of the corporate innovation ability.

\subsection{Recommendation}

In summary, two policy recommendations are proposed:

First, for the government, the introduction of high-education talents is an important measure to enhance the transformation of innovation in China, China should continue to adhere to the talent introduction and implementation policy, better play the role of academic-type talents in driving company innovation, lead China's IT companies to increase strategic investment in innovation. Meanwhile, academic-type executives with prominent educational background shall be appointed as managers of company innovation, their independent innovation capacity shall be improved, and more policy and regulatory support by government shall be given. 
Moreover, from the companies perspective, increasing the number of academic-type executives help to reduce the costs of innovation decision-making, consequently improving the overall innovation ability of the company. Companies shall comprehensively consider academic-type executives, leveraging academic knowledge and expertise of academic-type executives, and pay attention to the appropriate probation period for academic-type executives.

\section{References}

Amunkete, S., \& Rothmann, S. (2015). Authentic leadership, psychological capital, job satisfaction and intention to leave in state-owned enterprises. Journal of Psychology in Africa, 25(4), 27I-28I.

Buckley P.J., Clegg L.J., Cross A., Liu X., Voss H., Zheng P.(2010). The Determinants of Chinese Outward Foreign Direct Investment. In: Foreign Direct Investment, China and the World Economy. Palgrave Macmillan, London.

Chen, J., Zhu, Z., \& Yuan Xie, H. (2004). Measuring intellectual capital: a new model and empirical study. Journal of Intellectual capital, 5( I), 195-212.

Chon, M. (2017). Trademark goodwill as a public good: brands and innovations in corporate social responsibility. Lewis $\&$ Clark L. Rev., 21, 277.

Cui, Y., Zhang, Y., Guo, J., Hu, H., \& Meng, H. (2019). Top management team knowledge heterogeneity, ownership structure and financial performance: Evidence from Chinese IT listed companies. Technological Forecasting and Social Change, I40, I4-21.

Damanpour, F., \& Schneider, M. (2006). Phases of the adoption of innovation in organizations: effects of environment, organization and top managers I. British journal of Management, I7(3), 2I5-236.

Erickson, B. H. (2017). Good networks and good jobs: The value of social capital to employers and employees. In Social capital (pp. 127-I58). Routledge.

Forbes, D. P. (2005). The effects of strategic decision making on entrepreneurial self-efficacy. Entrepreneurship theory and practice, 29(5), 599-626.

Hinterhuber, A. (2004). Towards value-based pricing-An integrative framework for decision making. Industrial Marketing Management, 33(8), 765-778.

Hambrick, D. C., \& Mason, P. A. (1984). Upper echelons: The organization as a reflection of its top managers. Academy of management review, 9(2), 193-206.

Hollenbeck, J. R., \& Jamieson, B. B. (2015). Human capital, social capital, and social network analysis: Implications for strategic human resource management. Academy of Management Perspectives, 29(3), 370-385.

Huang, T., \& GE, Y. H. (2018). Impact of overseas experience of top management team on enterprises' innovation performance: the empirical study of information technology listed companies.

Jinhua, Z. (2010). Top Management Team Demographics, Social Capital and Corporate Performance(Doctoral dissertation, Huazhong University of Science and Technology, Wuhan, China). Retrieved from http://www.hust.edu.cn/

Kaplan, R. B., Murdock, L., \& Ostroff, F. (I99I). Core process redesign. The McKinsey Quarterly, (2), 27-44.

Kaplan, R. S., \& Norton, D. P. (200I). Transforming the balanced scorecard from performance measurement to strategic management: Part I. Accounting horizons, I5(I), 87-104.

Kenney, M., Breznitz, D., \& Murphree, M. (2013). Coming back home after the sun rises: Returnee entrepreneurs and growth of high tech industries. Research Policy, 42(2), 39I-407.

Liu, F. C., Simon, D. F., Sun, Y. T., \& Cao, C. (2011). China's innovation policies: Evolution, institutional structure, and trajectory. Research Policy, 4O(7), 917-931.

Lämsä, A. M., \& Takala, T. (2000). Downsizing and ethics of personnel dismissals— the case of Finnish managers. Journal of Business Ethics, 23(4), 389-399.

Lee, T. S., \& Tsai, H. J. (2005). The effects of business operation mode on market orientation, learning orientation and innovativeness. Industrial Management \& Data Systems, IO5(3), 325-348.

Li, Y., Zhao, Y., \& Liu, Y. (2006). The relationship between HRM, technology innovation and performance in China. International journal of manpower, 2777), 679-697.

Lopez-de-Silanes, F. (2017). The rise and decline of nations: the dynamic properties of institutional reform. https://doi.org/I0.1017/SI744137417000017

Mo. J. (2016).Research on the Impact of Overseas Background of Senior Management Team on Enterprise Innovation Performance(Master's thesis, Dalian University of Technology,Dalian,China).Retrieved from https://search.cnki.net/

Menguc, B., \& Auh, S. (2006). Creating a firm-level dynamic capability through capitalizing on market orientation and innovativeness. Journal of the academy of marketing science, 34(I), 63-73.

Matthyssens, P., Vandenbempt, K., \& Berghman, L. (2006). Value innovation in business markets: Breaking the industry recipe. Industrial Marketing Management, 35(6), 75I-76I. 
Mom, T. J., Fourné, S. P., \& Jansen, J. J. (2015). Managers' work experience, ambidexterity, and performance: The contingency role of the work context. Human Resource Management, 54(SI), sI33-sI53.

Opper, S., Nee, V., \& Holm, H. J. (2017). Risk aversion and guanxi activities: A behavioral analysis of CEOs in China. Academy of Management Journal, 60(4), I504-I530.

Porter, M. E., \& Kramer, M. R. (2019). Creating shared value. In Managing sustainable business (pp. 323-346). Springer, Dordrecht.

Peterson, R. (2004). Crafting information technology governance. Information systems management, 2I(4), 7-22.

Simsek, Z. (2009). Organizational ambidexterity: Towards a multilevel understanding. Journal of management studies, 46(4), 597-624.

Teece, D. J. (2010).Technological Innovation and the Theory of the Firm: The Role of Enterprise-Level Knowledge, Complementarities, and (Dynamic) Capabilities.https://doi.org/I0.10I6/S0I69-7218(I0)01016-6

Tan, J. (200I). Innovation and risk-taking in a transitional economy: A comparative study of Chinese managers and entrepreneurs. Journal of Business Venturing, I6(4), 359-376.

Wang. L. (2014).Research on the Relationship between Demographic Characteristics of Senior Management Team and Corporate Performance-An Empirical Analysis Based on GEM Listed Companies (Master's thesis, Southwestern University of Finance and Economics, Chengdu, China).Retrieved from http://www.swufe.edu.cn/

Wright, M., Clarysse, B., Lockett, A., \& Knockaert, M. (2008). Mid-range universities' linkages with industry: Knowledge types and the role of intermediaries. Research policy, 37(8), I205-I223.

Zhou, H. (2018). The impact of human capital of returnee CEOs and senior management teams on corporate innovation (Master's thesis, Hunan University, Changsha, China). Retrieved from http://www.hnu.edu.cn/

Zahra, S. A. (1995). Corporate entrepreneurship and financial performance: The case of management leveraged buyouts. Journal of business venturing, IO(3), 225-247.

\section{Copyrights}

Copyright for this article is retained by the author(s), with first publication rights granted to the journal. This is an open-access article distributed under the terms and conditions of the Creative Commons Attribution license (http://creativecommons.org/licenses/by/4.0/). 